\title{
Studying a Controversy amongst Pashtuns of Torghar, Balochistan, Pakistan
}

\author{
Luc Bellon
}

\section{OpenEdition}

\section{Journals}

Electronic version

URL: http://journals.openedition.org/samaj/213

DOI: 10.4000/samaj.213

ISSN: 1960-6060

\section{Publisher}

Association pour la recherche sur l'Asie du Sud (ARAS)

\section{Electronic reference}

Luc Bellon, «Studying a Controversy amongst Pashtuns of Torghar, Balochistan, Pakistan », South Asia Multidisciplinary Academic Journal [Online], Free-Standing Articles, Online since 05 October 2007, connection on 30 April 2019. URL : http://journals.openedition.org/samaj/213 ; DOI : 10.4000/ samaj.213

\section{(C) $\Theta \Theta \Theta$}

This work is licensed under a Creative Commons Attribution-NonCommercial-NoDerivatives 4.0 International License. 


\title{
samaj South Asia Multidisciplinary Academic Journal
}

Bellon, Luc (2007) 'Studying a Controversy amongst Pashtuns of Torghar, Balochistan, Pakistan', South Asia Multidisciplinary Academic Journal, URL : http://samaj.revues.org/document213.html. To quote a passage, use paragraph (§).

\section{Studying a Controversy amongst Pashtuns of Torghar, Balochistan, Pakistan}

\author{
Luc Bellon
}

\begin{abstract}
Much has been written about the political structures of tribal groups. The present article looks at political dynamics amongst Pashtuns of Balochistan, through the prism of a controversy. The sociological interest of studying the arguments used during a controversy has been underlined by Boltanski and Thevenot. A controversy finishes by the establishment, through consensus, of a common agreement upon accepted norms, determined limits, redefinition of social values, etc.. The advantage of focusing on the argumentation itself is to avoid taking the agreement as a pre-established social truth, a reference that concerned people would reluctantly challenge. To study a controversy is to study the social realities in the making, to study the archaeology of collective consensus, to reinstate history, contingencies and individual plurality within the social dynamics and to take seriously their performative actions alongside other social determinisms. This article shows that to study controversy is a way not only to set light on political dynamics and structures, but also to discuss the impact and definition of concepts such as segmentarity, equality, rights, interests, and their relevance within the Pashtun society which was observed.
\end{abstract}


Bellon, Luc (2007) 'Studying a Controversy amongst Pashtuns of Torghar, Balochistan, Pakistan', South Asia Multidisciplinary Academic Journal, URL : http://samaj.revues.org/document213.html. To quote a passage, use paragraph (§).

\section{The object of study: political interactions and social realities in the making}

[1] This study focuses on a group of Pashtuns living north of the Balochistan Province of Pakistan. Pashtuns are a 'tribal' ${ }^{1}$ group claiming anywhere between 37 to 40 million $^{2}$, the bulk of which living in the southern half of Afghanistan (around 12.5 million) and the western parts of Pakistan (estimated to be more than 28 million, of which 3.5 million are believed to be residing in Balochistan Province itself). The study has taken place in a mountainous area called 'Torghar', claiming a little more than 2,000 souls in about 2,700 $\mathrm{km}^{2}$, and situated in the District of Qilla Saifullah.

[2] Much has been discussed about the political set-up of 'tribal' societies and the values that it conveys. Debates have attempted to qualify the nature of the political negotiations which are at play through notions such as 'equity', 'hierarchy', '(pre)democracy', etc. In the case discussed here, these qualities seem ill fitted to resume the pragmatic or ideological basis of the political dynamics that we observed. Rather, the references used by the actors vary constantly and can encompass all the above. Therefore, 'political set-up' 3 is considered not only as defining a set of pre-determined roles and statuses granting socially accepted power to agents, but also as the process which is followed and by which political decisions are taken.

[3] A political interaction is first and foremost an act, or an action. Social determinisms may induce directions and frames for this act to happen. Social determinisms can also result from its outcome, i.e. the political decisions taken or agreements reached. But if we consider an

1 The word 'tribal' has been used in several contexts and criticized as being a colonial construct which essentialize ethnic identities. Yet, it has also led to depict social setups sharing common traits such as the genealogical links - agnatic societies -; economic activities - pastoral nomadism -, attitudes towards conflict - feuds and guerrilla -; means of decision making - councils -; values and principles - code of honour -; etc. Although these traits vary, and do not suffice to characterize a group, social scientists have kept referring to 'tribal societies', undertaking comparative studies on this basis. The aim of this article is not to discuss the validity or sociological relevance of the term. The word 'tribal' is used here not to stress essential characteristic of the people, but, rather, to highlight relevant social traits known to be existing elsewhere: for this reason, it is systematically employed within quotes.

2 There are no accurate population censuses which account accurately for the Pashtun population. Although known to be inexact, the most reliable estimates are believed to lie with the government of Pakistan and the official sources of Afghanistan. For such statistics, the following web pages can be consulted:

http://www.statpak.gov.pk/depts/pco/statistics/demographic indicators98/demographic indicato rs.html, http://www.statpak.gov.pk/depts/pco/statistics/other tables/pop by mother tongue.pdf, https://www.cia.gov/cia/publications/factbook/geos/af.html

3 'Political' is understood in its epistemological sense, i.e. actions destined to create a collective consensus from which social organization and understanding are derived. 
Bellon, Luc (2007) 'Studying a Controversy amongst Pashtuns of Torghar, Balochistan, Pakistan', South Asia Multidisciplinary Academic Journal, URL : http://samaj.revues.org/document213.html. To quote a passage, use paragraph (§).

'action', as Hannah Arendt does, as an event, a birth, by which contingencies, the unexpected, the surprising occur and reveal the subject ${ }^{4}$, then a political action is an act of creation that reconciles social determinisms with the fluctuations of individual motivations, including diversity, variability, discontinuity and instability. As such, to study political interactions can unveil social realities in the making.

[4] The object of the present article is, precisely, what unfolds to be relevant during a negotiation. This should enable us to look simultaneously at what the situation triggers - in this case, an NGO's program introducing a specific need for actors to position themselves -, the anchorages it finds in pre-existing references and social relations, and what individuals make out of it.

\section{The Context - an NGO's attempt to blend in}

[5] Considered as an action, political interactions need to be observed through a specific event emerging from within a situation. In the present case, the situation is that of a series of negotiations between an NGO specialized in the sustainable use of natural resources, and the inhabitants of Torghar. The centre of our interest here is to use a relationship (the NGO and the inhabitants) to access events taking place within. The aim is not to discuss, or even less to evaluate, the actions of the NGO itself, but to pay attention to the political interactions which are triggered within this situation.

[6] The NGO, called STEP (Society for Torghar Environmental Protection), was designed only to intervene in Torghar. Its aim is to encourage the sustainable use of natural resources. More specifically, it focuses on conserving two animal species - a wild goat (Markhor) and a wild sheep (Urial). In order to save the animals - to preserve the natural resources -, STEP has convinced the mountain's inhabitants to ban hunting. The 'sustainable use' is done through the coming of trophy hunters (a few every year) who pay an important sum to hunt one animal; these hunters are very few in number and the animal they hunt is carefully controlled, so as to assure that the animal population retains its normal growth rate [this is not very clear: to prevent people from hunting the Ngo gives trophies to hunters? Yes, that is the principle]. Trophy Hunting is the almost exclusive source of income for the program.

\footnotetext{
${ }^{4}$ On action considered as natality, see Arendt (1994: 231-314).
} 
Bellon, Luc (2007) 'Studying a Controversy amongst Pashtuns of Torghar, Balochistan, Pakistan', South Asia Multidisciplinary Academic Journal, URL : http://samaj.revues.org/document213.html. To quote a passage, use paragraph (§).

[7] The NGO is a small structure ${ }^{5}$ set up by a Pashtun - hereafter referred to as ' $\mathrm{N}$ ' - who comes from another area (Pishin District, Balochistan). Although Pashtun, $\mathrm{N}$ does not belong to the same tribe as Torghar inhabitants: the later are Kakar whereas $\mathrm{N}$ is Tareen. Pashtuns are patrilineal, thereby inheriting tribal affiliations through males. But, despite being Tareen, $\mathrm{N}$ benefits from matrilineal links with the chief section of the Kakar, his sister being married to one of them. Hence, although being an outsider by tribe, $N$ holds a 'maternal uncle' (mama) status within this portion of the tribe. Although many considerations can be drawn from this point, the one that retains our attention now is the fact that STEP is not entirely an external structure from the point of view of the Torghar inhabitants.

[8] The concept of 'sustainable use of natural resources' differs from simple conservation in that it enables to draw benefits from the resources which are conserved. The benefits generated by Trophy Hunting are not only used to finance the running costs of the NGO, but are meant to generate income for the program beneficiaries, i.e. the inhabitants of Torghar. In this case, the benefits are redistributed, for the main part, in the shape of salaries for game guards, all living in the mountain, as well as through the construction of dams, water pipes, levelling of dirt roads, etc.

\section{The Methodology - active observation and passive interference}

[9] I have carried field research in Torghar during a total of 17 months, the bulk of which was during the year 2002. My post of observation was participative inasmuch as I was officially employed by the STEP to conduct a 'social assessment' of the program. Although my terms of reference remained vague until the end, my presence in the mountain was unquestionably connected with the work of the NGO. My participation in whichever debate I witnessed has remained indirect, in the beginning because I did not know the language, and later on as a result of my explicit methodological stand. 'Indirect participation', means that I shared directly my opinions regarding the issues raised by or around STEP's program only with $\mathrm{N}$ and, after many months, with two game guards. My opinions, often distorted, were many times referred to by $\mathrm{N}$ during the collective or individual discussions he would hold. This would often aim at

\footnotetext{
5 The organization is managed by a total of five people. The main office is run by three people: a chairman, a Director of Finance and a Director of Tribal Management. A regional office in Qilla Saifullah (capital of the District to which Torghar belongs) comprises of a Director of Tribal Affairs and a Coordinator.
} 
Bellon, Luc (2007) 'Studying a Controversy amongst Pashtuns of Torghar, Balochistan, Pakistan', South Asia Multidisciplinary Academic Journal, URL : http://samaj.revues.org/document213.html. To quote a passage, use paragraph (§).

strengthening his case by calling upon the opinion of an outsider. Later on, the same opinions, yet again distorted, would be cited by some of N's interlocutors back to him, again to assert a point of view. As I spent most of the time taping the conversations that were taking place, 'I' (as an entity more than an individual) became the guarantor of what had been said. If one was to recall an argument proffered previously, my presence would be sought to guarantee the veracity of the assertion. In such cases, I would retain my 'neutral' stand and avoid replying, but the performative aspect of my reference remained very much intact.

[10] There would be much more to say about my presence, role and participation in the negotiations which took place between the NGO and the inhabitants. Yet, what has been previously explained suffices for the purpose of this article: to analyze the arguments used during an observed controversy. In any case, to put myself back into the following description would only marginally increase the understanding of the stakes, as I made sure to never participate directly in the debates (so as to avoid bringing additional or external arguments in the influx of the controversy). As far as what is being discussed here is concerned, my main interference has been towards strengthening or arguing N's stand, which will be briefly described below.

[11] The discussions that I have witnessed ${ }^{6}$ are mostly linked to a project of creating 'Mountain Committees' to increase the ownership and direct management of the program by Torghar inhabitants. I was officially linked to this project and ended up drafting, in a written form, and based on discussions spread over 8 months, the bye-laws of these committees and their relationships with the overall structure of STEP. These discussions led to conversing about a wide range of subjects.

[12] I have paid particular attention to the means by which a development NGO manages (wilfully or not) to penetrate the intricacies of the social fabric of this Pashtun mountain. Therefore, the threshold of my observation has been the interactions and negotiations which have taken place between the NGO and the inhabitants.

\section{The notion of 'justification' as a theoretical background}

[13] Before going into the description of the specific controversy that I chose to discuss, I must explain the foreseen interest in undertaking such a study. To study a controversy is to set

\footnotetext{
${ }^{6}$ Many of these discussions have been taped - 156 hours, 92 of which have been literally transcribed. Most of the data used for this article come from these recordings and the quotations of Torghar inhabitants, which follow, are all extracted from them.
} 
Bellon, Luc (2007) 'Studying a Controversy amongst Pashtuns of Torghar, Balochistan, Pakistan', South Asia Multidisciplinary Academic Journal, URL : http://samaj.revues.org/document213.html. To quote a passage, use paragraph (§).

light on the 'regimes of justification' that the actors use to enforce their stand. Regimes of justification are here understood as arguments presented by the actors, during the controversy, and before the occurrence of judgment. These arguments belong, or are attached, to a set of references, or fields, which are commonly shared and accepted. They are 'justifications' in so far as they are validated by the actors and give sense and legitimacy to a stand. Justifications are used to reach an agreement, which then sets the possibility of a judgment.

[14] To focus on regimes of justification means to take seriously the arguments and rationales that are put forth and to understand which fields of arguments are used, as well as how they are made to be efficient. Taking justifications seriously means, as Boltanski and Thevenot have underlined (Boltanski \& Thevenot 1991), to consider them as making sense, being objective, rather than being part of an imaginary construct (prenotions, ideologies, alienation, or belief) or fictions elaborated for the sole purpose of maintaining stability and social order. To focus on justification implies to distinguish acceptable arguments (which are justifications) from unacceptable connections of principles (which are not). Unacceptable connections of principles do not make the principles themselves invalid, but they are being dismissed in the way they are being called upon in the given situation. In other words, a controversy is a situation whereby principles are put to test, and where the general conditions for their validity in the formation of a judgment are being laid by the actors themselves.

[15] Along with the principles at work, a controversy also reveals the competence of persons or concepts, which actors put forth to engage or settle their dispute. The dispute is a crisis, understood not as a moment of chaos, but a moment when the course of action comes to a standstill, and demands to re-establish a common agreement, that is, a common reality. Indeed, disputes (controversies within them) are occasions during which the actors expose and unfold verbally their actions. Thus, they tend to generalize and retain, themselves, what is or can be of general worth. The agreement is reached by accepting a common reality, the latter being created through the use and activation of regimes of justification. Regimes of justifications are therefore both enabling and creative.

[16] Hence, regimes of justification are both: 1) a means of considering socials determinisms as acting principles guiding social interactions, thus recalling what Bourdieu 
Bellon, Luc (2007) 'Studying a Controversy amongst Pashtuns of Torghar, Balochistan, Pakistan', South Asia Multidisciplinary Academic Journal, URL : http://samaj.revues.org/document213.html. To quote a passage, use paragraph (§).

highlighted through his notion of 'habitus"; and 2) to include in the analysis what the "habitus' deliberately omits: the plurality of human identity, i.e. the capacity of individuals to act and react autonomously, thereby having a direct effect on the social fabric they evolve in ${ }^{8}$.

[17] The method of observation that I used focuses on explicit enunciations, rather than postulating an implicit (unconscious) reference which only a social analysis could unveil. This means avoiding to reduce individuals to the quality or qualification they bare at the time of the controversy; or, in other words, to avoid explaining their actions as following mechanical or systematic trends designed by the social 'structure' to which they belong - a social structure being paradoxically both internalized by, and exterior to the actors. Though there are surely mechanical implications to accept the validity of a set of common references, these are not sufficient to understand the behaviours and social dynamics in a given context. By focusing on the negotiation taking place between the organization and the inhabitants, I chose to remain as close as possible to the movements and considerations of the actors.

[18] That is not to say that what is observed is nothing more than juxtapositions of contingent interests. While accepting that individuals may find ways (through violence for example) to bypass principles for the benefit of their interest, ambitions, needs or wants, sociology is able to describe these contingencies only at the time when these acts are restored in the public / collective sphere. This point is close to the one made by Monsutti concerning friendship: he shows that among Hazara and in the context of migration, friendship is a crucial factor for alliance making, and that the relationships which are attached to it cannot be understood in the light of segmentarity or descent principles alone (Monsutti 2004). Contingencies should not be discarded, nor their consequences ignored, as it is precisely about the consequences, and not the contingency itself, that social science has something to say.

\section{The context of the controversy}

[19] The sociological stakes that lie behind the study of a controversy having been described we can now look at the controversy itself. This paper concentrates on the negotiations which unfold while discussing the acceptable principles to be adopted by STEP for re-distributing

\footnotetext{
${ }^{7}$ For the most explicit definition of the notion of 'habitus', understood as 'sustainable and transposable dispositions', see Bourdieu (1980: 88).

${ }^{8}$ Comparing Ricoeur's and Bourdieu's approaches, Gérome Truc (2005, p. 47-67) demonstrates that while the notion of 'habitus' is a tool by which the social determinisms and their performative strength can be highlighted, it also unjustifiably abandons the possibility of analyzing contingencies as part of the observable social dynamics.
} 
Bellon, Luc (2007) 'Studying a Controversy amongst Pashtuns of Torghar, Balochistan, Pakistan', South Asia Multidisciplinary Academic Journal, URL : http://samaj.revues.org/document213.html. To quote a passage, use paragraph (§).

the financial benefits obtained through Trophy Hunting. The main question being: how to establish a principle of equity, which could serve as a basis for distribution and be acceptable to all potential beneficiaries?

[20] The distribution of benefits has led to much tension, as many in the mountain felt deprived of their share (haq: lit. 'right'); whether jobs or development work. There was constant contestation about the way it had been given or distributed. Added to that, STEP, never came up with (or imposed) a defined system of distribution, thereby it was functioning on ad hoc basis. The tensions culminated into several controversies, yet only one of them is analyzed in the present article. By doing so, I focus my attention on the social dynamics unravelled during the controversy. The aim is, therefore, to: lay down the foundations which led the controversy to arise; expose what the controversy is about; unfold the different arguments which are used within the controversy; and understand what kind of precedent the agreement sets, its innovation and potential use.

[21] The controversy is essentially based on the fact that on one hand, the NGO considers 'the mountain' as the most relevant unit for its action, therefore identifying its inhabitants as a single 'community' and the rightful beneficiary of the program. By doing so, it establishes a parallel between beneficiaries and 'owners' of the mountain (the land). On the other hand, the inhabitants identify themselves as being part of different agnatic groups each owning a part of the mountain. In this respect, the reasoning along the lines of a single 'community' sharing a common interest lacks relevance. Furthermore, the ownership of the mountain is understood as being that of each group as a whole, therefore comprising those group members who live outside the mountain. Where the NGO considers the 'owners' as being the 'inhabitants', the inhabitants themselves cannot make that link, and include as owners those living elsewhere'.

[22] The organization uses the concept of 'community' as encompassing the whole of the mountain. STEP employs 'Jalalzai' as a generic term to name this community. The Jalalzai are a branch of the Kakar, which fall under the authority of the dominant group, the Jogizai. The Jogizai themselves are Jalalzai, but usually name 'Jalalzai' all other group, except themselves, falling under their authority. In addition, if the Torghar inhabitants are effectively all Jalalzai, all Jalalzai do not belong to Torghar, far from that. Hence, the use of this term to identify the Torghar community is only valid with regards to non-Jalalzais, but cannot be held as a term that identifies

\footnotetext{
${ }^{9}$ For more details, see Bellon (2005: 109-23).
} 
Bellon, Luc (2007) 'Studying a Controversy amongst Pashtuns of Torghar, Balochistan, Pakistan', South Asia Multidisciplinary Academic Journal, URL : http://samaj.revues.org/document213.html. To quote a passage, use paragraph (§).

them as opposed to non-inhabitants of Torghar. The absence of a satisfactory term to name this 'community' reveals the social construct undertaken by NGO in naming a 'community' which does not exist.

[23] Although this conceptualization of a group solidarity, which does not exist, is the starting point of the tensions, it is not on this very concept that the controversy took place. In fact, to call upon mountain solidarity was neither challenged, nor taken into account, despite the straightforward attempts by the organization to enforce the idea. This attempt is best exemplified by N's claim to establish 'companionship' (mulgari) amongst all participants of the program, meaning amongst the inhabitants as well as between them and the administrators. Companionship is a word widely used to depict random associations of people, with no reference to status (for example, going somewhere with someone, or doing anything together, will be qualified as 'doing mulgari'). The immediate goal was to detach the relationships linked to the program from any hierarchical consideration, relations of power or domination. The program was to be accepted on a free-will basis rather than imposed by authoritative methods, and meant for the benefit of all (the members of the Torghar 'community'), not for the powerful ones. By that, it should not get entangled in the local disputes, and should transcend grudges.

[24] This generous and equalitarian idea was never contested, but establishing such a relationship was never made effective. Hierarchical relations remained intact, including with $\mathrm{N}$ who never shed his identity not only as an 'elder' - due to both his age and his above-mentioned matrilineal links with the dominant group of Jalalzais - but also as a 'sardar' (chief) ${ }^{10}$. The inhabitants called him by that title (sardar) and extended to him the same ostentatious forms of respect they would for any other person of such rank. Yet, the reason why the proposed equality was never contested is that $\mathrm{N}$ constantly justified his stand by calling upon the commonly accepted and valued principle of helping the poor and needful through collective effort and solidarity. This stand bares strong moral values which led many interlocutors towards harsh self criticism, such as: 'us Pasthuns, we are no good / we are dishonest, we are not trustworthy nor

\footnotetext{
${ }^{10} \mathrm{~N}$ 's father was the chief his tribe. Although his position was inherited by N's elder brother, it is common that all the male descendants of a chief using the title (sardar) as a term of reference. This usage induces effective respect from, and power over, other Pashtuns. Despite the fact that $\mathrm{N}$ belongs to a different tribe, the inhabitants of Torghar validate the deference linked to his status, and, in the controversy, this rank gives weight to his word and stance.
} 
Bellon, Luc (2007) 'Studying a Controversy amongst Pashtuns of Torghar, Balochistan, Pakistan', South Asia Multidisciplinary Academic Journal, URL : http://samaj.revues.org/document213.html. To quote a passage, use paragraph (§).

worthy of the trust of God, / you have come to distribute benefits to us, but we are destroying our own land / we are poor and ignorant and we don't understand / fraternity has ended"11.

[25] If equality was never enforced it is also because the organization and the benefits it brings have continuously been entangled in internal conflicts. Although most people deplored this state of affairs no one seemed to find it avoidable. Hence, part of the reason why the idea of equality and help was never enforced, despite winning the approval of all, is that it could not account for creating common interest. In fact, the relevance of considering the mountain's people as one group was never discussed. At most, it leads to assert that if the distribution of benefits is rightfully done, these problems will be solved. To summarize, although recognized as valid, this conception of solidarity has failed, by being approved yet ignored, to procure a basis for establishing a system of distribution of the benefits.

[26] The idea of 'equality' defended by $\mathrm{N}$ implies equality of rank. The 'mulgari' relationships command not to refer to each other's status. Interestingly, this very idea became the basis and the reference upon which the controversy developed, but it did so along very different conceptions of equality and rights. Rather than defining what the actors should do - which would have been the case if these arguments had become the foundations for a principle of distribution - it defined the constraints within which the argued regimes of justification needed to remain. As will be explained below, the regimes of justification put forth during the controversy by the Torghar inhabitants are of a different nature and need not be evaluated in the light of N's. N's arguments are simply other. Although the controversy could have opposed the NGO's principles of equality to those valued by the Torghar inhabitants, it became one between the inhabitants themselves with reference to the arguments imposed by $N$ and the viability of STEP's program.

\section{What the controversy is about - rights, inheritance and equality}

[27] Why and how did the simple and accepted principles of STEP's program initiate a debate that led to a controversy? As said above, STEP considers the inhabitants of the mountain as a single 'community' which owns the land; rational by which it has been able to identify the program's beneficiaries. Yet, the issues of distribution and collective ownership were translated into something that the NGO did not mean or expected.

\footnotetext{
${ }^{11}$ Assertions repeatedly heard throughout the multiple debates that I witnessed, and proffered by many of N's interlocutors to comfort him in the righteousness of his arguments.
} 
Bellon, Luc (2007) 'Studying a Controversy amongst Pashtuns of Torghar, Balochistan, Pakistan', South Asia Multidisciplinary Academic Journal, URL : http://samaj.revues.org/document213.html. To quote a passage, use paragraph (§).

[28] The program began in 1985 with limited income, and started hiring game guards to protect the mountain from hunters. Throughout the years, the number of game guards increased and became the major asset distributed by STEP to the mountain's people. As it increased, Torghar inhabitants claimed right to the job on the basis of being owners of the mountain as well. In 1998, two local tribal sub-groups sat together to reach a common agreement establishing a criterion for distributing jobs. This was initiated and reached without the intervention of STEP. These groups are A1a(ii) and A1a(iv), the latter being further divided into 4 agnatic groups - see figure below. Altogether, they detain approximately one third of the program area. This agreement was written on a 'stamped' government paper, therefore giving it an official and legal status and the shape of a 'contract' between the members of the tribe. 


\section{Figure 1: Genealogy of agnatic groups inhabiting Torghar}

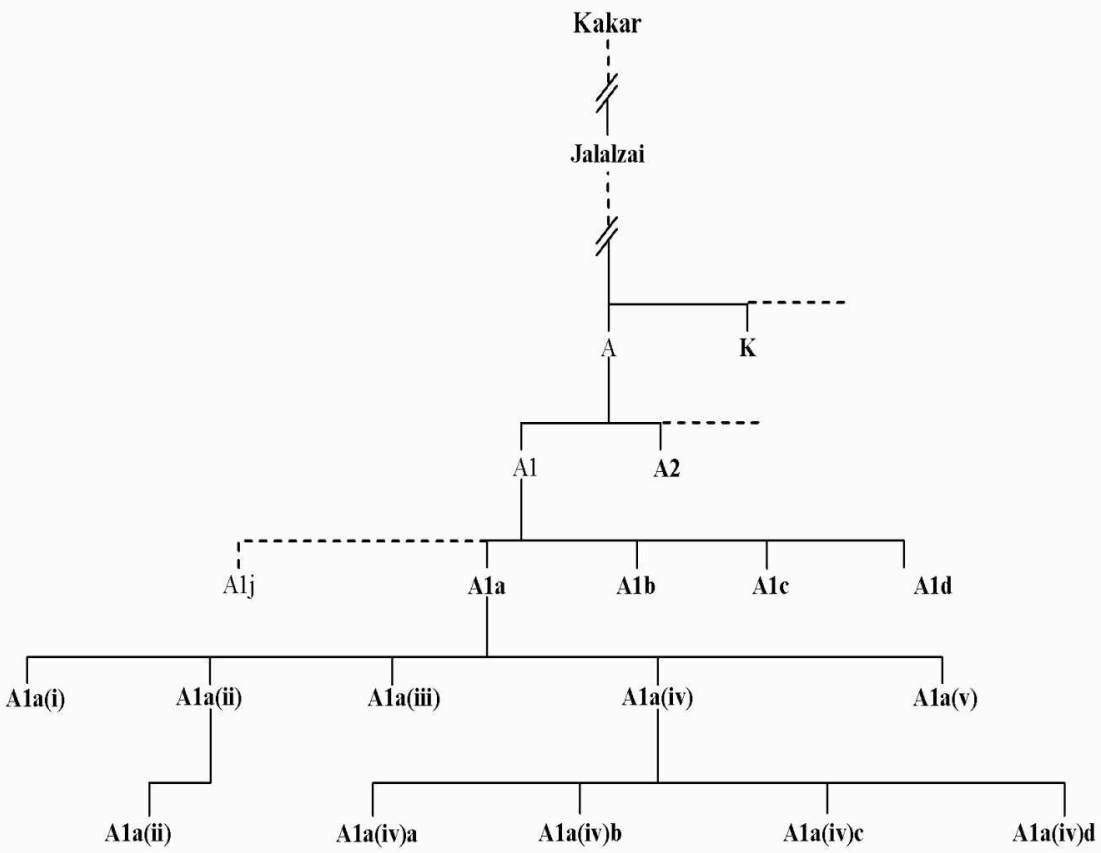

[29] Notes: The names in bold are those, used by the inhabitants of Torghar, to name themselves. The lowest rank of the genealogy is 5 to 7 generations away from the living inhabitants. From there, continuous lines indicate single generations difference. For each subgroup on the lowest rank, the population living in the mountain varies between 100 and 400 individuals. Same is the case for groups such as A1b, A2 or K. The status of A1a(ii) is particular: A1a(ii) died at a young age, after having a son. His wife married A1a(iv) and gave birth to A1a(iv)b. In the meantime, A1a(ii) took the place of his father, therefore considered on the same genealogical level as him. Depending on issues (as will be seen in the controversy exposed in the present article), this may also be challenged, reason for which A1a(ii) appears on both levels.

[30] In the eyes of the NGO, the main achievement of this contract was to assert the fact that the wildlife belongs to no-one in particular, rather it is to a 'collective ownership' corroborating STEP's attempt to bring together the 'Torghar community' around a common project. This assertion is further based on a widely accepted Islamic principle that living things, at their natural state (not domesticated), cannot be owned by human beings. The NGO believed this to be the 
Bellon, Luc (2007) 'Studying a Controversy amongst Pashtuns of Torghar, Balochistan, Pakistan', South Asia Multidisciplinary Academic Journal, URL : http://samaj.revues.org/document213.html. To quote a passage, use paragraph (§).

open door for the 'people of the mountain' to agree upon sharing collectively and equally the benefits deriving from those animals, since no group could claim precedence over this asset.

[31] Upon closer scrutiny, the question of ownership of the animals is merely a side assertion. The written agreement puts forward the problem as follows:

[32] It first states the initial claims of each group:

- $\quad \mathrm{A} 1 \mathrm{a}(\mathrm{ii})$ demands the same share as $\mathrm{A1a}$ (iv), basing its claim on the fact that being a brother, he ${ }^{12}$ is treated as a son - therefore on the same genealogical level as that of the descendants of $\mathbf{A} 1 \mathrm{a}(\mathrm{iv})$.

- $\quad \mathrm{A} 1 \mathrm{a}$ (iv)a states that the land concerned by the program is collective, therefore it cannot be inherited and the benefits should be distributed on the basis of the population. As far as game guard jobs are concerned, one should be given per 80 individuals, and based on rotation.

- $\quad \mathrm{A} 1 \mathrm{a}(\mathrm{iv}) \mathrm{b}$ states that he agrees with this principle of population.

- $\quad \mathrm{A} 1 \mathrm{a}(\mathrm{iv}) \mathbf{c}$ et $\mathrm{A} 1 \mathrm{a}(\mathrm{iv}) \mathbf{d}$ demand an equal share to the other groups (A1a(iv)a and $\mathbf{A} 1 \mathrm{a}(\mathbf{i v}) \mathrm{b})$, meaning one fourth of the share given to $\mathbf{A} 1 \mathrm{a}(\mathrm{iv})$, based on the grounds that their common ancestor were brothers.

[33] In demanding an equal share to their 'brothers', A1a(ii), A1a(iv)c and A1a(iv)d insist on the principle of inheritance by which what is inheritable must be distributed equally amongst 'brothers'. In this case, the benefits generated by the program are considered as deriving from inheritable collective property. This argument is contested by another point of view, defended by the 'arbitrator' of this agreement (member of $\mathbf{A 1 a ( i v ) a ) ~ a n d ~ b y ~ t h e ~ a g r e e m e n t ~ i t s e l f . ~ T h i s ~ p o i n t ~ o f ~}$ view claims that the land with which the program is concerned (on which lives the wildlife) is collective and undivided, therefore not falling into inheritance, whereby the distribution of benefits should be based on the population of each group.

[34] The interest of this controversy lies with the fact that the two propositions do not exclude one another. Rather, they both belong to radically different spheres of justification: one

12 In Pashto, the groups and sub-groups, being named after the common ancestor - for example, Arab Khails are descendants of Arab - are referred to with singular pronouns. Linguistically, they are treated as individuals, with attributed acts, needs, demands, etc. As a matter of fact, treating collective groups as individual characters has contributed to the acceptation of N's address to the 'Torghar community' as a singular entity. 
Bellon, Luc (2007) 'Studying a Controversy amongst Pashtuns of Torghar, Balochistan, Pakistan', South Asia Multidisciplinary Academic Journal, URL : http://samaj.revues.org/document213.html. To quote a passage, use paragraph (§).

based on genealogy (plar) and the other on demography (nafari). The possibility of raising the demographic factor is a direct consequence of N's initial stand: there are no differences between inhabitants and all should be treated equally. However, the implications for those who have raised it are radically different, if not opposite, from N's idea.

\section{The first set of arguments - equity and demography}

[35] As for most disputes, an arbitrator designated with the approval of all concerned parties must take the decision. In this case, the arbitrator is the malik ('village' chief) of A1a(iv), himself member of $\mathbf{A 1 a ( i v ) a . ~ W h a t ~ f o l l o w s ~ a r e ~ t h e ~ a r g u m e n t s ~ u s e d ~ ( b o t h ~ i n ~ t h e ~ w r i t t e n ~}$ agreement, and in the course of conversations) in favour of the population-based [nafari] distribution.

- $\quad$ Benefits are not inheritance.

[36] Not all assets fall under inheritance, and namely not collective (sharik) land, which has not been divided. Apart from the individually owned land (a small portion of the overall land, with individual ownership registered by the government), the program area comprises of 'collective' and undivided land. This 'collective' land falls into two categories: the mountain (uncultivable, therefore undividable at all) and the pasture land (cultivable but undivided). This pasture land belongs to tribal or sub-tribal groups, but is not possessed by any individual or family. Potentially, anyone from the concerned group is entitled to graze its herds on it. Those from other groups - nomadic groups especially - can also use these lands, if granted permission from the 'owners'. This permission is seldom refused. The limit of to the usage can only be made through collective agreements, to rotate its use or, eventually, to leave it fallow. The Malik writes in the agreement that 'it is the custom [riwa] of Jalalzai [wider tribe of Pashtuns, potentially excluding others, but making it a rather general statement] that benefits derived from pasture land are divided on the basis of the population'. Therefore, the distribution of benefits from the program cannot fall under the principle of inheritance or under the shari'a law.

- $\quad$ Responsibility, solidarity and the Law of God.

[37] Because the land is collective, it is a collective responsibility to protect it. Considering that some families are poorer and/or less numerous than others, they cannot take upon themselves the burden of the whole tribe. They cannot be expected to guard the mountain (their 
Bellon, Luc (2007) 'Studying a Controversy amongst Pashtuns of Torghar, Balochistan, Pakistan', South Asia Multidisciplinary Academic Journal, URL : http://samaj.revues.org/document213.html. To quote a passage, use paragraph (§).

portion) with so much facility as those families who claim more people. One cannot burden the weak. Therefore the benefits (and namely the game guard jobs) should be distributed according to a principle based on population. This follows the principle by which khairat (charity which does not fall into zakat, which can be made at the discretion of an individual as a sign of remembrance or thankfulness to God) is conducted, arguing that when killing a sheep and distributing it, one will give shares of meat to houses according to the population they contain. The religious and moral legitimacy of the argument leads a game guard (member of $\mathrm{A} 1 \mathrm{a}(\mathrm{iv}) \mathrm{a})$ to assert: 'this nafari (population) system is in conformity with sharia and will please God'. The equality of rights of individuals is also put forth as an Islamic principle, as the following citation exemplifies: 'A person per head. This is the right of a person. There is one man, he has five sons. Out of the five, one son has only one son in turn, the other four have ten sons each. (...) In that case, this one son has an equal share to the ten brothers from the other plar. We say no, even God's book says that this is a man's share'. (A1a(iv)a, game guard, March 2002).

- $\quad$ Conflict and loot.

[38] In case of conflict, those in favour of 'nafari' argue that it is not fair to demand the same participation in the warfare from groups / houses of unequal sizes. Participation to the conflict, as well as the distribution of the loot, should be calculated according to the population of each family / group. 'What if tomorrow there is a conflict, or if the tribe has to host someone of importance [thereby having to kill a sheep, etc.] or if someone has to be corrupted?' asks A1a(iv)a (school teacher, February 2002). This argument is reinforced by a recent decision (spring 2001) taken over the distribution of land won through a dispute. This dispute engaged a large number of tribes. It ended up in government courts and it was decided to divide it according to the size of each group.

- In conformity with the Law.

[39] Against the very loose notion of $h a q^{13}$, the written agreement states explicitly that the collective sharing of pasture land is in conformity with Islamic, national and international law. In terms of national law, a similar issue has been raised (and cited as an example) vis-à-vis the distribution of jobs (levies or coolies, etc.). The attribution of jobs (and mostly levies / militia), initiated by the British colonial administration, combines both nominal jobs and others given to the

${ }^{13} \mathrm{Haq}$ is ambivalent in Arabic as it means, simultaneously, 'the truth of one thing', 'to have such right' and 'to be of duty, of necessity'. See Montigny (2000: 51-74.) In Pashto, it is used in the sense of undisputed right, of a thing's due share. 
Bellon, Luc (2007) 'Studying a Controversy amongst Pashtuns of Torghar, Balochistan, Pakistan', South Asia Multidisciplinary Academic Journal, URL : http://samaj.revues.org/document213.html. To quote a passage, use paragraph (§).

tribe at large based on rotation. Recently (2001), a tribe has won a case in court for transforming nominal jobs into tribal jobs, therefore making them under rotation. The similarity in shape (jobs) enables an easy shift from one principle of reference to another. Although the distribution of jobs by STEP obeys a specific logic, the fact that they are jobs gives them an ambivalent identity, possibly pulling them back to a status invented at the time of colonization, and confirmed by laws, which are followed up to this day.

[40] With these arguments, the benefits (deriving from collective land - and not individual property) are excluded from the system of inheritance. As such, they are not considered collective property, but as an ownerless asset which fruits - as it is true for pasture land or wild fruit trees can be shared collectively. This stand is justified by a certain regime of morality, called upon through the reference to Islam. It also suggests, by claiming to be geared at protecting the poor and weak, the primacy of individual solidarity over collective solidarity.

[41] The collectivity conceived as a sum of individuals is, in that sense, in conformity with N's initial proposal to consider the benefits as being for the inhabitants. It differs, however, in that it continues to see the tribe as a relevant collective reference. The individuals are counted within their respective agnatic groups. As the mention of the governmental jobs suggests, the claim also reinforces the differentiation between agnatic groups based on their demographic strength. This means retaining the tribal affiliation as a main element of self-identification, the right to inheritance as a valid principle, and the collective identity as being different from 'the inhabitants of Torghar'.

\section{The second set of arguments - equity and genealogy}

[42] The opposing arguments favour considering the distribution of benefits based on family units; this means taking the genealogical links as a primary source of discrimination. With regards to the controversy, the arguments are developed as follow.

The principle of inheritance applied to land.

[43] The program is based on land and land is distributed on the basis of plar (father) [you translated plar by 'genealogy' and now by father, check]; that is to say, every tribal group or sub-group can lay claim to a specific portion of land as part of their inheritance. Even though the collective land has not been divided, it belongs, in right, equally to each father. The division happens at a given generation, therefore amongst brothers. In conformity with Islam, the division 
Bellon, Luc (2007) 'Studying a Controversy amongst Pashtuns of Torghar, Balochistan, Pakistan', South Asia Multidisciplinary Academic Journal, URL : http://samaj.revues.org/document213.html. To quote a passage, use paragraph (§).

of inheritance between brothers must be of equal shares. The land which is not inheritable is the 'mountain' land where the wildlife lives. But the adjacent land - in the gorges, plains and plateau are cultivable and therefore can, potentially, be distributed. Considering this principle of division, the land that has to be protected is of equal size for each tribal group (at a same genealogical level), therefore an equal number of jobs should be distributed to each group.

Conflicts.

[44] In most conflicts, an equal contribution (human or financial) is required of each group (plar, ie. 'father'). There are many examples of such conflicts, including in recent times where each group had to give an equal amount $(25,000$ rupees) in order to provide for the court case expenses. According to such logic, the principle of equality of each agnatic group prevails and should constitute the basis for distributing benefits, as costs and benefits should be shared in the same way.

- $\quad$ Equality of rights - the Law of God.

[45] To base the distribution on the comparative demographic weight can be seen as a direct attack on the rights (haq) of each group to claim an equal portion from its equals. It could be, for example, considered un-Islamic to distribute inheritance unequally between brothers, based on the fact that a brother has more children than another. 'If God has made one group more numerous than another', it does not entitle that person to take over more land (game guard, member of $\mathrm{A} 1 \mathrm{a}$ (iv)c). Some of the owners of the land do not live in the mountain. Therefore, on the count of population, they end up with a share when they are not present to protect the mountain. Basing the distribution on the mountain's population ends up negating the right of the individuals who can claim a share to the mountain but do not live in it. Moreover, those groups claiming the most people are also the most powerful and richer groups in the mountain. To distribute a greater amount of benefit to them is to increase the imbalance between groups whom are meant to be 'equals'.

[46] The main stand defended by these arguments is to safeguard the equality of rights for each agnatic group. As for those based on individual solidarity, they are in conformity with STEP's principles: this position argues in favour of equal distribution amongst segments of equal value, leaving the internal distribution of those shares up to the group concerned. But considering the mountain as an isolated group is still not possible. This regime of justification is entrenched in lineage-based hierarchy. The rights are established according to pratrilineal descent: the 
Bellon, Luc (2007) 'Studying a Controversy amongst Pashtuns of Torghar, Balochistan, Pakistan', South Asia Multidisciplinary Academic Journal, URL : http://samaj.revues.org/document213.html. To quote a passage, use paragraph (§).

collective land belongs to a single ancestor and must be distributed equally between the sons. The maintenance of this hierarchy maintains equality of rights and power balance amongst agnatic groups, disregarding the population or the political strength of each group. In that, it levels off the demographic inequality by giving primary importance to hierarchical patrilineal descent.

\section{A fragile agreement}

[47] The controversy therefore opposes equality of rights (haq) to equality of needs. Each borrows justifications from a different set of principles. The coexistence of the two models - in a similar way as Fabietti has shown it to be true between equality and hierarchy amongst the Baloch of Makran (Fabietti 1996) - is justified, in this case, by the fact that they do not contradict each other, but belong to distinct spheres of references.

[48] These two sets of arguments are clearly different from the ones that STEP has put forth. But they both align values, which aim at not contradicting the latter. STEP's basis for trying to achieve collective solidarity is used, by the first set of arguments, to claim demographic strength. Similarly, where STEP advocates for equality between 'owners', the second set of arguments demands equality between agnatic groups. We understand, therefore, that the NGO is not participating directly in this debate, despite playing a major role in setting the frame of the controversy. Although having led incessant discussions on the matter, $\mathrm{N}$ did not take part in the argumentation that he has proposed, other than re-asserting his stand. Also believing in selfdetermination, his attitude was to leave the inhabitants to find the best-suited agreement. As a result, the arguments used and discussed amongst the inhabitants continued to obey another set of objectives, while seeking approval by $\mathrm{N}$ on basis of the fact that it would not contradict his point of view. $\mathrm{N}$ has been used to re-validate the arguments employed by them.

[49] But the common judgment, which is necessary for agreement to take place, is based on a fragile consensus. Just as those in favour of a distribution based on population have to extract the benefits (made 'collective' by the organization) from inheritance - thus constructing a reality through verbal justifications -; those opposed to it do not challenge the value of solidarity.

[50] In order for distribution to be population-based, the benefits have to be qualified as non-inheritable. To do so means placing them out of reach of lineage hierarchy. Yet, the agnatic groups remain a reference for distribution, including households. To make this system of distribution viable, it has to escape the temporality of the hierarchy. The proposed process of 
Bellon, Luc (2007) 'Studying a Controversy amongst Pashtuns of Torghar, Balochistan, Pakistan', South Asia Multidisciplinary Academic Journal, URL : http://samaj.revues.org/document213.html. To quote a passage, use paragraph (§).

rotation is a good illustration, as it opposes a conception of jobs belonging to individuals, ad vita aeternam, based on their tribal stand ${ }^{14}$. The rotation based on population retrieves these jobs from the genealogical timeframe. By joining several groups together in bulks of 80 , the rotated job can no longer be attributed to a specific descent. Therefore, and in order to assure - theoretically - the good application of such a system, a 'committee' was designed to appoint all new jobs and the order of rotation.

[51] The emergence of nafari (population) as a principle applied to the distribution of benefits led to the creation of a new value based on pre-existing regimes of justification. The domain of application is unprecedented, but is based on existing 'grandeur' and worlds of reference (Boltanski \& Thevenot 1991). To refer back to what was said in the introduction, the principle is acceptable inasmuch as it does not invalidate the principle of inheritance. It becomes unacceptable when it leads to replacing the existing system of distribution of inherited assets (even in parts).

[52] Yet, despite the written agreement, the population principle still faces opposition, even amongst the most populated group ( $\mathrm{A} 1 \mathrm{a}$ (iv)a), amongst segments of that segment, down to the patrilateral parallel cousin (Father's Brother's Son - FBS) ${ }^{15}$. The contestation is based on the assumption that bypassing the collective rights of agnatic groups enables the group to assert the dominance of their demographic weight. In such case, individually based equality creates inequality amongst agnatic groups, while not abolishing their existence. In other words, the distribution to individuals will reinforce the power of the groups (household, branch and tribe) to which they belong. The two stands over equality (equality of individuals $v / s$ equality of groups) must not override one another since self identification linked to patrilineal descent is recognized in both cases. But the potential encroachment has not, in effect, fully been avoided. This is partly owed to the fact that, since the benefits are generated by its exploitation, the issue of distribution cannot be dissociated from the issue of land (which, when owned, falls into inheritable property). Such encroachment makes the two considerations of equality conflicting.

\footnotetext{
${ }^{14}$ Which was, as mentioned earlier, the principle by which some of the government jobs were, and are, distributed in the Balochistan Tribal Areas, ever since the British period.

15 The terbur (patrilateral parallel cousin, FBS) is always depicted as the closest ally and the most immediate potential enemy. Relationships with terbur are complex and do not follow systematic patterns. But the specificity of his position is that of being the closest kin who is not inscribed in the genealogical hierarchy, but whose inheritance is only one generation away from one's own. For a discussion on this figure much talked about in anthropological literature, especially concerning the Pashtuns, see, amongst others, Lindholm (1996) and Ahmed (1980).
} 
Bellon, Luc (2007) 'Studying a Controversy amongst Pashtuns of Torghar, Balochistan, Pakistan', South Asia Multidisciplinary Academic Journal, URL : http://samaj.revues.org/document213.html. To quote a passage, use paragraph (§).

\section{Land status, distribution and the ambivalence of ownership}

[53] Land ownership is the arena (as described elsewhere) of many tensions and conflicts $^{16}$. The explicit reference to land and 'owners' by the program stresses the bind to these conflicts and increases the opposition to base distribution on nafari (population). The land of A1a(iv) and A1a(ii) has been conquered after a feud, therefore not falling in the common inheritance of the wider tribe.

You have to understand how distribution is done. (...) Even shariat does not understand it well (an elder of A1a(iv)a, July 2002).

[54] Collective (or 'shared') ownership is based on agnatic groups. Although the land is owned collectively, whether inheritable or not, it is divided along the lines of these groups and divided within. All groups and sub-groups are in a position of claiming boundaries to their collective land, even that which has not been divided. Such is the case at different levels of the subdivision. The collective areas are usually determined according to the direction in which the water flows from a peak downwards. Vertical delimitation is based on the streams, each bank belonging to one or another group. The demarcations of collective land (which is not inheritable generally referred to as 'the mountain') can easily be (and are constantly being) challenged.

[55] The occupation of land can be several generations old, and has either been acquired through capturing vacant land (padari), taken as settlement to a dispute, or bought. Whether the land has been occupied or won, its boundaries are maintained for the most part by the perpetuated memory of the events that led to the group's establishment. This memory is mostly oral and transmitted through the 'elders'. Hence, for example, it is not rare that the words of one's father, minutes before his death, are recalled upon as a source of knowledge about the exact delimitation on the land. If those boundaries were contested, the claiming parties can take an oath on the Quran to assert their claim. Taking this oath in front of someone with recognized religious authority is one of the means by which the demarcations are reaffirmed. Wells are also important markers. They are usually part of the inheritance, therefore attributed to a specific family or group. When they are situated at the extreme end of a group's territory, the adjacent stream is considered as the demarcation for that group's collective land.

${ }^{16}$ For a critical analysis of how tribal grazing areas in Saudi Arabia were converted into state lands open to all, see Fabietti (2000). 
Bellon, Luc (2007) 'Studying a Controversy amongst Pashtuns of Torghar, Balochistan, Pakistan', South Asia Multidisciplinary Academic Journal, URL : http://samaj.revues.org/document213.html. To quote a passage, use paragraph (§).

[56] Ownership. The cultivable lands are mostly in the plains, and smaller portions on the plateaus. They can therefore be large portions of flat land, or small band. This originally collective land can be divided, if it is measured (raqba), amongst the members of a group along the principle of inheritance; otherwise it remains collective. The division takes place when the tribe splits, often following a conflict between the sections. Once divided, it thenceforth becomes a sailable commodity - which is one of the ways through which ancestors have acquired land. The selling and buying of land is not uncommon, though not frequent.

[57] Added to that, there are two cases of ownership, which excludes the land from collective inheritance:

- Ownership gained through buying land from another person, usually from another tribe and often adjacent to the collective territory. Once bought, the land becomes part of the buyer's asset, and detached from any other collective inheritance ${ }^{17}$.

- Ownership through the registration of land with the government on the grounds that it is cultivated and / or exploited (construction of wells, construction of houses, etc.). This can be done on disowned land or undivided collective tribal land. In Torghar, the only such occurrences have taken place on small portions of 'mountain' land. They are developed into small agricultural patches called and considered karwanda (garden, i.e. cultivated patch). This land also falls out of the collective inheritance and back into the owner's. It is to note that this mode of acquisition does not belong to any kind of 'tribal' logic - in terms of the way the land is distributed - but is justified by government law which, itself, is drawn from the Islamic principle of granting ownership for exploited land.

[58] The program area comprises each of these categories of land ownership. But the mountain portion explicitly mentioned in the agreement is limited and does not include the land which $\mathrm{A} 1 \mathrm{a}$ (iv) or $\mathrm{A} 1 \mathrm{a}$ (ii) have bought and which are adjacent to their collective land. It also rules out the privately owned gardens and, most of all, says nothing about the potential ulterior division of this collective land. The agreement remains vague, stating the outer boundaries of the collective territory, but not mentioning the internal distinctions.

17 'When land is sold, and small parcels often are, a first option to purchase lies with the nearest collateral agnates who (...) would otherwise stand to inherit it. The sharia doctrine of haqq-i-shaff (the right or interest of the neighbour in one's real estate) is interpreted (...) to apply first to those who have divided what previously was whole' (Anderson 1983, pp. 137-38). For a comparative discussion on the evolution of land rights in Balochistan, see Scholz (2002). 
Bellon, Luc (2007) 'Studying a Controversy amongst Pashtuns of Torghar, Balochistan, Pakistan', South Asia Multidisciplinary Academic Journal, URL : http://samaj.revues.org/document213.html. To quote a passage, use paragraph (§).

[59] The fear of those opposed to the distribution based on population is that this system will apply to inheritable land or goods. As one inhabitant puts it: 'for seven generations, we have had one scale of measurement. Now, on the 8th generation, if he (malik) comes up with a new scale, we are going to have problems' (member of A1a(iv)a, January 2002).

\section{How the controversy links to power}

[60] The fear is further increased by the ambivalent status given to jobs, with reference to a history of jobs granted by the government to the tribes. Indeed, the indirect rule initiated under British Raj has linked the attribution of jobs - levies, coolies and other - to the recognition of the tribes, their status, power and territorial rights. These jobs are still being attributed today along more or less the same lines. The amalgamation of government jobs with those provided by the program was explicit, especially during the initial years: some who demanded to be game guards were being refused by other game guards based on the fact that they were already employed by the government. Similarly, as government jobs - linked to repairing roads, for example - have been given to tribes based on the land they possess, some game guard jobs have also been linked to land ownership. Instances have occurred where the fact of being hired by STEP for guarding the mountain has put forth by groups to assert their land rights.

[61] By that token, giving a higher number of jobs to one group is feared to lay a basis for land claim. Although unfounded in terms of inheritance, it is not unconceivable for it to bear weight if a conflict was to arise. In fact, this is precisely the argument raised by the malik concerning a single job given to another group (A2) living on the outskirt of the program area. A1a(iv)a got recently involved in a conflict with this group over a portion of land which includes two gorges in the mountain. The malik has demanded that the organization retrieves the job given to a member of $A 2$, claiming that it could be used as proof of land ownership by $A 2$ in the conflict.

[62] Indeed, this echoes previous situations. One of which is the following: A1a(iv) is involved into a dispute still unresolved after some 70 years; one of the initial triggers to the land claim is the fact that two jobs had been given to the opposing party for the construction of a dirt road situated in the middle of the disputed land; the existence of these jobs has been used as evidence in court for claiming the land.

[63] Another possible link between the game guard jobs and land rights concerns the status of written papers. The value given to writing - discussed elsewhere (for example, see 
Bellon, Luc (2007) 'Studying a Controversy amongst Pashtuns of Torghar, Balochistan, Pakistan', South Asia Multidisciplinary Academic Journal, URL : http://samaj.revues.org/document213.html. To quote a passage, use paragraph (§).

Hamès 2004) - as element of proof, or officialization, especially during trials, is partly derived from the fact that the boundaries of collective property are easily challenged. The lack of incontestable proof gives increased value to the written element. Therefore, writing plays an important role in the status given to the game guard jobs, which are known to be registered, and all the more so as the game guards have to sign (thumb print) every month upon reception of their salaries.

[64] Finally, there is a project conceived by the defenders of the nafari principle which they do not deny: to bring it beyond its actual acceptable competence. Some members of A1a(iv)a affirm their ambition to use this precedent -distributing benefits according to the population's number - as a basis for later distribution of collective (but dividable) land. The threat is all the more acute as A1a(iv)a has the most population within the mountain, and withholds the majority of the land which has been registered with the government - the latter, therefore, cannot be considered as part of the inherited share / the tribe's inheritance. Although no action has been taken in that respect - and rumours have amplified the issue - some of those accused have openly asserted this to be a future plan.

\section{$X$. Elements of discussion}

[65] Our close scrutiny of this specific controversy reveals several interesting points. One is the possibility of understanding how apparently incompatible principles actually co-exist. This has been noticed by many authors (Fabietti 1996, Kraus 1998, Cole 2003) who emphasized on their contradictory aspect. Here, the principles are revealed within a set of autonomous arguments, and are each given specific competences. Hence, focusing on justifications may be a way of understanding how the coexistence is made possible.

[66] Also, the concept of solidarity appears, through this prism, under a different angle. Insofar as solidarity defines the help extended to others (as opposed to safekeeping one's own interest), it is valid outside any reference to the lineage hierarchy. Hence, solidarity is inscribed in a-temporal relations. The introduction of temporality, in the case of distribution of wealth, calls back the lineage hierarchy. In this respect, aziz is an interesting and ambivalent notion. It refers to close kin, with no reference to status, and is normally used for justifying extended help (giving food, not paying fares in a bus, etc.). The solidarity is justified by a kinship loosely or contextually defined, but will stop short in front of any imperative of alliance or opposition to another group. 
Bellon, Luc (2007) 'Studying a Controversy amongst Pashtuns of Torghar, Balochistan, Pakistan', South Asia Multidisciplinary Academic Journal, URL : http://samaj.revues.org/document213.html. To quote a passage, use paragraph (§).

Aziz will only be referred to as long as the identification in the lineage is not made explicit. To treat someone as an aziz is to treat that person with solidarity as long as the person's specific genealogical identity is not relevant.

[67] The lineage hierarchy is first and foremost a matter of self identification (Anderson 1983, Tapper 1983). It is striking to find that tribes are referred to in the first or third person singular. It assigns a place to individuals and a status which differs depending on the temporalities considered. A brother has equal rights once the father is dead, but is either younger or older when he is alive. The terbur falls out of that hierarchy, whereby becoming a potential threat, but is part of 'me' (A1a(iv) for example) when the place which is referred to is at the level of an ancestor. Rather than fission and fusion, it would tend to suggest a certain ubiquity of individuals - which seems to echo Marcus's multi-site theory (Marcus 1999) with the sites bearing both synchronic and diachronic dimensions. It also underlines a time dependency very close to the network theories (Moody 2002).

[68] Power and domination are not put forward as a set of justification and often lead to the absence of a common agreement. As a matter of fact, four years after the agreement had been reached, I was told:

Malik has imposed this decision because no one can afford to go on war / feud (badi) against him. He is at least three to four times more than we are. It is like you have connections to America, to the government, to the officials and you're rich, but my jaws are tied, I am dumb, I am poor, so you (malik) are doing all this by the virtue of your strength' (member of A1a(iii) October 2002)

[69] Looking at controversy may be a way to reduce the gap underlined by Schlee between an explanation of conflict based on the interest of groups on one hand, and the opposite stand whereby conflict is explained in terms of identity mechanical or principle-based clashes (Schlee 2004). In the present controversy, the nafari principle has been conceived as tool for building power. Although people are assigned to specific places within the hierarchy, it does not determine political roles. I would therefore argue that the segmentarity is self identification, but not a political structure.

[70] My findings suggest that much more could be discussed using the methodology derived from Boltanski and Thevenot's work on justification. Yet, as far as my research is concerned, it proves to be an efficient way of describing interactions in their entirety, including the uncertain identities and positions of individuals, and their effect on collective consensus. 
Bellon, Luc (2007) 'Studying a Controversy amongst Pashtuns of Torghar, Balochistan, Pakistan', South Asia Multidisciplinary Academic Journal, URL : http://samaj.revues.org/document213.html. To quote a passage, use paragraph (§).

\section{References}

Ahmed, A. S. (1980) Pukhtun Economy and Society. Traditional Structure and Economic Development in a Tribal Society, London, Boston \& Henley: Routledge \& Kegan Paul.

Anderson, J. W. (1983) 'Khan and khel: dialectics of pakhtun tribalism', in R. Tapper (ed.), The Conflict of Tribe and State in Iran and Afghanistan, New York: St. Martin's Press, pp. 119-149.

Arendt, H. (1994) [1961] Conditions de l'homme moderne, Paris: Calmann-Lévy.

Bellon, L. (2005) 'From Hunting to Sustainable Use. A Pashtun Tribal Group's Innovations, North Balochistan, Pakistan', in J. Velasquez, M. Yashiro, S. Yashimura, \& I. Ono (eds.), Innovative Communities: People-Centered Approaches to Environmental Management in Asia- Pacific Region, New York: United Nations Press, pp. 109-23.

Boltanski, L.; Thévenot L. (1991) De la justification. Les économies de la grandeur, Paris: Gallimard.

Bourdieu, P. (1980) Le sens pratique, Paris: Editions de Minuit.

Cole, D. P. (2003) 'Where Have the Bedouin Gone?', Anthropological Quarterly, 76 (2), pp. 235267.

Fabietti, U. (1996) 'Equality versus Hierarchy: Conceptualizing Change in Southern Balochistan', in P. Titus (ed.), Marginality and Modernity. Ethnicity and Change in Post-Colonial Balochistan, Karachi: Oxford, New York \& Delhi, Oxford University Press, pp. 3-27.

Fabietti, U. (2000) 'State Policies and Bedouin Adaptations in Saudi Arabia. 1900-1980', in B. Musallam (ed.), The Transformation of Nomadic Society in the Arab East, Cambridge: Cambridge University Press, pp.82-89.

Hamès, C. (2004) 'Parenté, prophétie, confrérie, écriture; l'islam et le système tribal', in H. Dawod (ed.), Tribus et pouvoirs en terre d'Islam, Paris: Armand Colin, pp. 17-37.

Kraus, W. (1998) 'Contestable Identities. Tribal Structures in the Moroccan High Atlas', Journal of the Royal Anthropology Institute (N.S.), 4, pp. 1-22.

Lindholm, C. (1996) Frontier Perspectives. Essays in Comparative Anthropology, Oxford \& Karachi: Oxford University Press.

Marcus, G. E. (1999) 'What is at Stake - and is not - in the Idea and Practice of Multisited Ethnography', Camberra Anthropology, 22 (2), pp. 6-14.

Monsutti, A. (2004) Guerres et migration. Réseaux sociaux et stratégies économiques des Hazaras d'Afghanistan, Neuchâtel \& Paris: Institut d'Ethnologie \& Maison des Sciences de l'Homme.

Montigny, A. (2000) 'Le territoire livré à l'arbitrage de Dieu. L'interprétation de la loi par les Al Na'im du Qatar', Etudes Rurales, 155-156, pp. 51-74.

Moody, J. (2002) 'The importance of relationship timing for diffusion', Social Forces, 81, pp. 2556.

Ricoeur, P. (1990) Sois-même comme un autre, Paris: Seuil.

Schlee, G. (2004) 'Taking Sides and Constructing Identities: Reflections on Conflict Theory', Journal of the Royal Anthropology Institute (N.S.), 10, pp.135-156. 
Bellon, Luc (2007) 'Studying a Controversy amongst Pashtuns of Torghar, Balochistan, Pakistan', South Asia Multidisciplinary Academic Journal, URL : http://samaj.revues.org/document213.html. To quote a passage, use paragraph (§).

Scholz, F. (2002) Nomadism and Colonialism. A Hundred Years of Baluchistan 1872-1972, Karachi: Oxford University Press.

Tapper, R. (1983) 'Introduction', in R. Tapper (ed.), The Conflict of Tribe and State in Iran and Afghanistan, New York: St. Martin's Press.

Truc, G. (2005) 'Une désillusion narrative? De Bourdieu à Ricoeur en sociologie', Tracés, 8, pp. 47-67. 